\title{
A Lecturer's and Students' Perspective toward Ethnic Snake Game in Speaking Class at Universitas Muhammadiyah Malang
}

\author{
Lulud Oktaviani ${ }^{1}$, Elsa Marina Desiarti ${ }^{2}$ \\ lulud_oktaviani@teknokrat.ac.id ${ }^{1}$, edesiarti@gmail.com² \\ Universitas Teknokrat Indonesia $^{1}$ \\ Universitas Muhammadiyah Malang ${ }^{2}$
}

\begin{abstract}
In the $21^{\text {st }}$ century era, technology has influenced on many aspects of life includes education. Thus, lecturers are demanded to apply it in teaching and learning process because it can help lecturers deliver the material in attractive ways to trigger the students' enthusiasm. There were still fewer technology usage in teaching and learning in speaking class as the researchers did a preliminary study (questionnaire) in Universitas Muhammadiyah Malang (UMM). The preliminary study showed that 63\% students said their lecturer never uses multimedia-based medium in teaching speaking, yet $89 \%$ students thought the usage in classroom was important. Answering the students' need, the researchers want to use a multimedia-based medium, Ethnic Snake Game, in speaking class for Electrical Engineering students in UMM. Thus, this research belongs to descriptive research. In using this multimedia-based medium, the lecturer and students showed positive responds.
\end{abstract}

Key Words: multimedia-based medium, game, speaking class

\section{Introduction}

The twenty first century is the century where technology cannot be separated in any aspects of life; it helps people socialize, shop, do transactional banking, learn, and so forth. People mostly are able to use and operate technology in life, even children, who are more recently known as digital native, can master the technology better than adult. Being aware of the wide range of using technology around digital native, lecturers are appealed to use technology or Computer Assisted Language Learning (CALL) in education aspect in order to attract students' attention, maximize their potential, and expand what they need to learn. It is in line with Smaldino, Lowther, \& Russel (2008: 5) who state that CALL, however, will help students learn beyond text book, not limited to the confines of the classroom, and help them achieve their highest potential regardless of their innate abilities. So, lecturers are demanded to choose which technology suits their ability and mastery. Preparing technology in teaching is not easy and takes time, but it is more long lasting than paper or other conventional teaching. Besides, it also can be used again and again and easier to carry around.

Apparently, using multimedia in teaching English skills (Reading, Listening, Writing, and Speaking) is developing among the teachers or lecturers. It is because the teaching and learning activities become more effective and interesting for students. In fact, the variation of teaching media is limited; the lecturers mostly only use power point or video for teaching reading, listening, writing, and speaking. Fortunately, these monotonous media usage stimulate the researchers to apply good and interesting media in a class, Ethnic Snake Game.

Ethnic Snake Game which is a multimedia-based medium (computer-based) which contains local wisdom such as some pictures about traditional clothes or foods in order to promote speaking skill for electrical engineering students at Universitas Muhammadiyah Malang (UMM). It is adapted from snakes and ladders game board which is modified and combined with technology. Originally, snakes and ladder is found in a book from India and played by using numbers that was written on the board, pawns and dice (Avedon, 2010). Recently, it has been modified regarding the material and rules. For example in teaching and learning process, teacher or lecturer will modify the board depending on what English skill or content he/she will teach. Ethnic snake game is game adopted from snake and ladder game but it was modified by adding some pictures from many places of Indonesia to make students aware of some cultures. There are three units in this multimedia; the first unit is "Describing Thing". The second unit is "Describing Person". The third unit is "Describing Object". Every unit is completed with warm-up activity, material, snake game, and quiz.

The students will play a game and monitored by the lecturer. First, the lecturer will divide students into several groups. Then, the students will spin the dice in line based on the number of the group. After that, the pawn will automatically move based on the number they get. Next, they need to describe (speaking) about the picture 
based on the instruction given below the picture within 15 seconds. If their answer is correct, the lecturer will click on check button $(\sqrt{ })$ and they can stay on the position and roll the dice again after others group play. However, if their answer is wrong, the pawn will automatically go back two steps. How to play this game is almost the same like snake and ladder game that are some pawn, dice, and board. The students' pawn will move based on the number after rolling the dice. If they are lucky, they get number on the board with a question and they need to speak based on the instruction shown within limited time. However, if they cannot speak clearly according to the lecturer, their pawn will go back two steps. The worst is unlucky number which they will get number on the board with skip turn caption, go back two steps, etc. Finally, the winner is the fastest student or group to reach finish line.

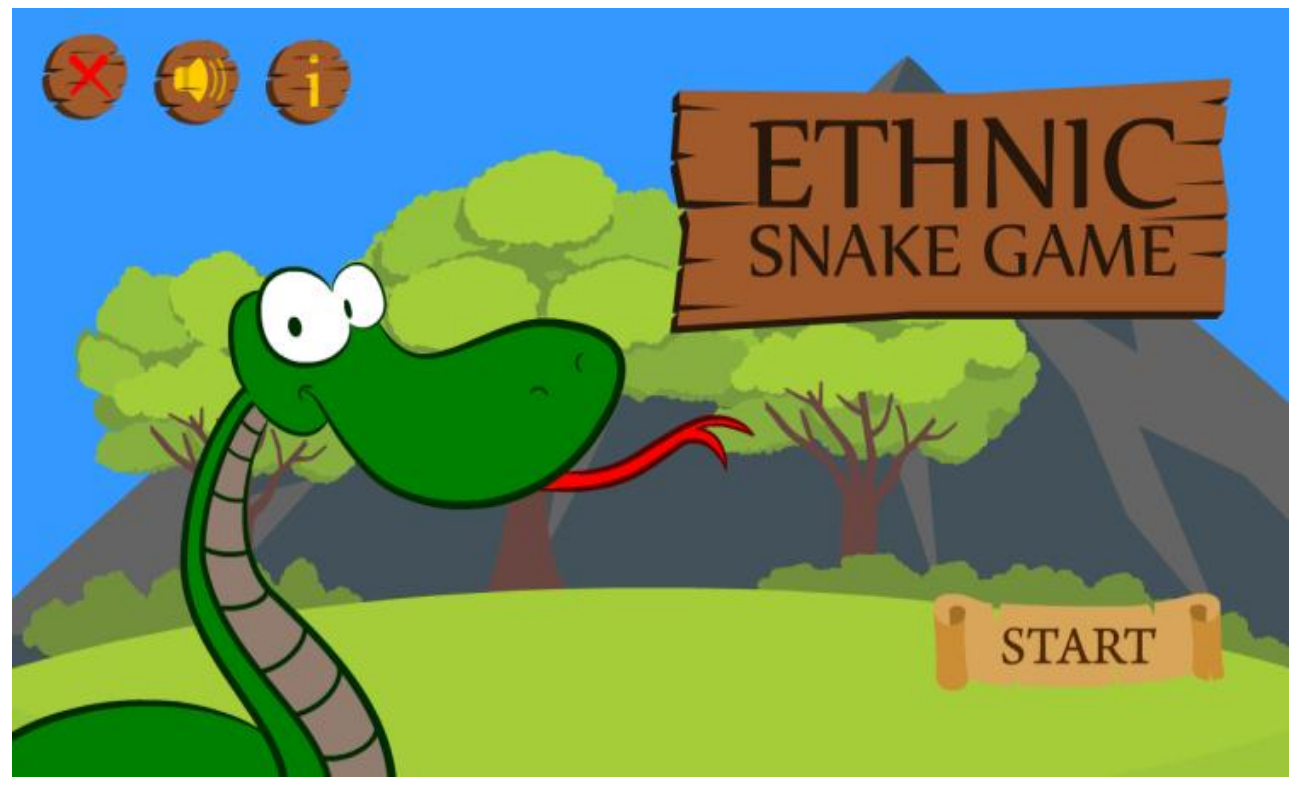

Figure 1. The first appearance of the multimedia game

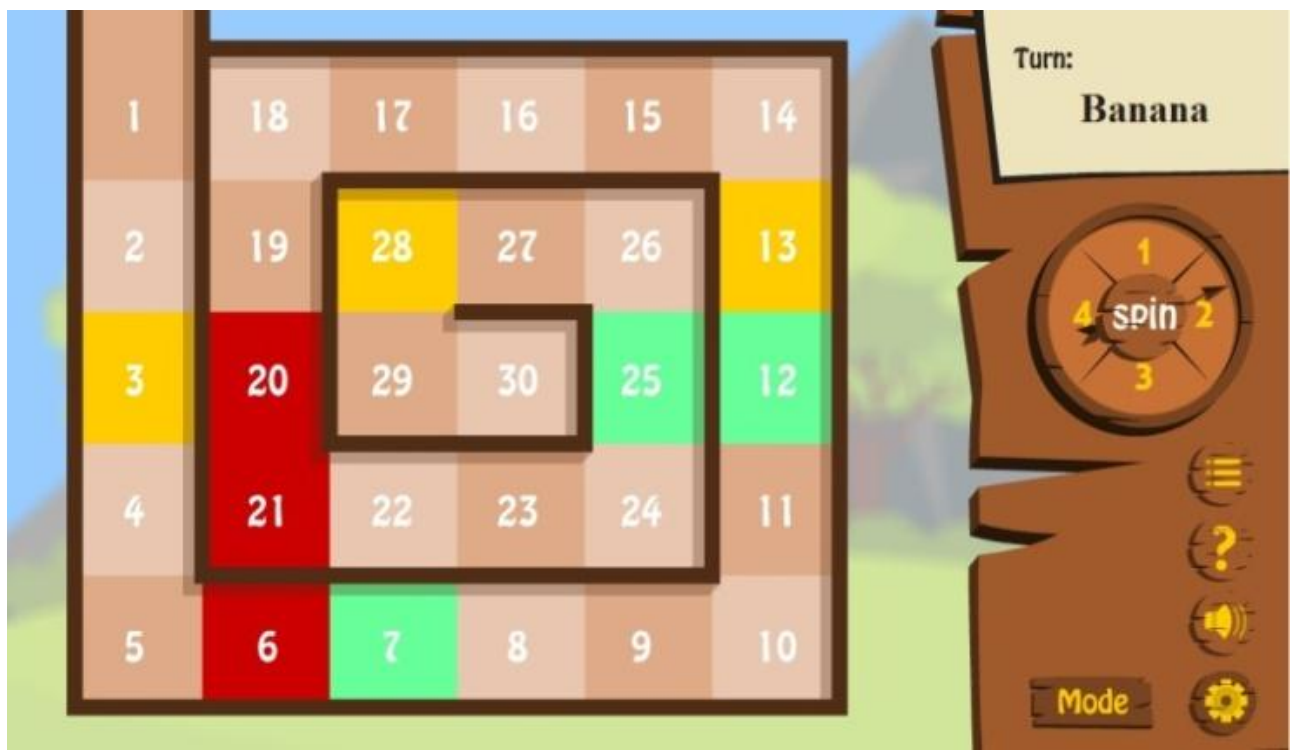

Figure 2. Ethnic snake game board 


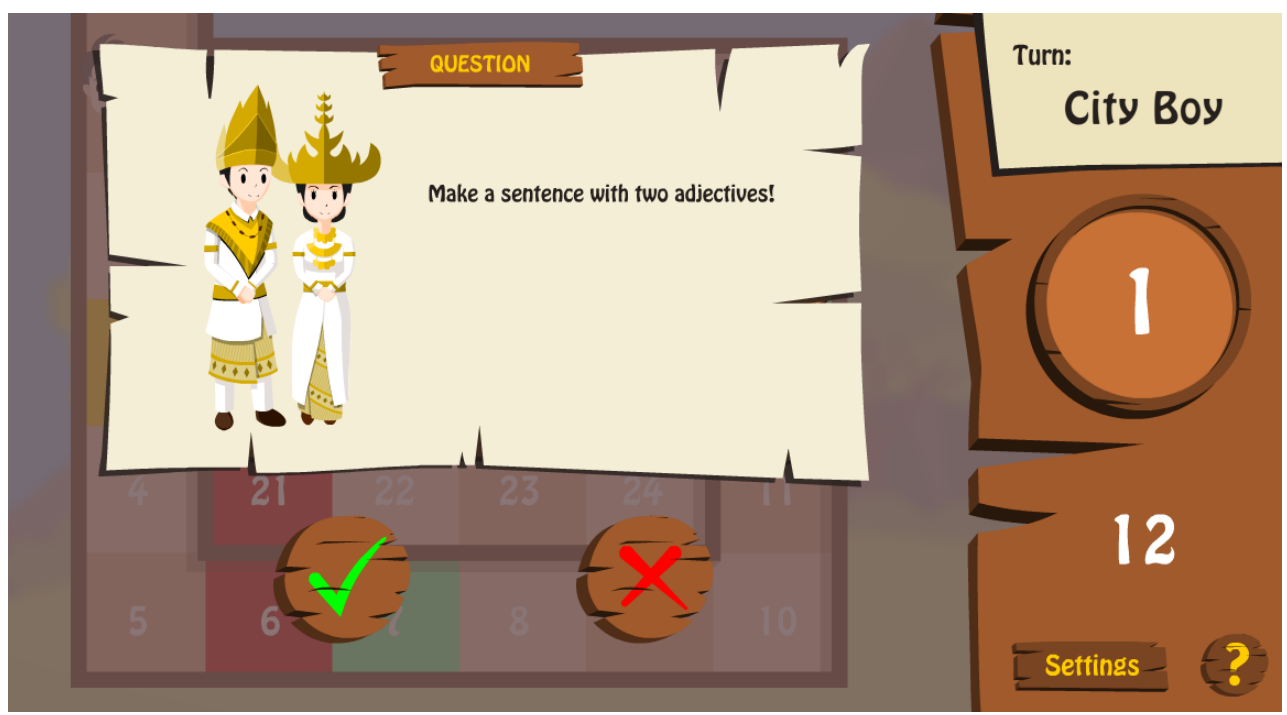

Figure 3. The example of the instruction after the students move their pawn

UMM, especially electrical engineering major is chosen by the researchers because both of the researchers were the alumni of this university and one of them is the ESP lecturers in this institution until now. So, the researchers had access to do a research in UMM. Moreover, the preliminary survey and book observation were conducted by the researcher by collecting the data from book analysis, giving questionnaire to students. Regarding the instruments, the researcher used questionnaire. Based on the preliminary survey in the form of questionnaire and book observation done by the researcher on December 19, 2015, there are some reasons why the researcher proposes a multimedia-based medium as an alternative medium for teaching ESP in UMM. First, the speaking activities in the book used by the ESP lecturer entitled English for Electrical Engineering (2014) are monotonous. The activities are mostly individual performance, group presentation, role-play, and making a dialogue. Second, ESP program in UMM is a model for other schools or universities that want to create the same program. It is proven by some universities or school who visited Languange Center (LC) UMM to have ESP study visit because some of them do not have an ESP program yet and some of them want to know about the syllabus, teaching and learning process, media used, and many more. The list of school and university are provided in the table below:

\begin{tabular}{|l|l|l|}
\hline No. & Name of the Institutions & Date of Study Visit \\
\hline 1. & University Muhammadiyah of Purwokerto & December 20, 2011 \\
\hline 2. & MAN Bangil & January 24, 2012 \\
\hline 3. & University Muhammadiyah of Jember & April 7, 2012 \\
\hline 4. & Politeknik Negeri Batam & April 8, 2014 \\
\hline 5. & University of Surakarta & January 24, 2015 \\
\hline 6. & University Muhammadiyah of Yogyakarta & February 4, 2015 \\
\hline 7. & SMAN 2 Mojokerto & October 13, 2015 \\
\hline 8. & University Muhammadiyah of Sukabumi & January 15, 2016 \\
\hline
\end{tabular}

Table 1. Study Visit to LC of UMM

Third, based on the questionnaires which given to the students showed that most of them wanted to have various activities in learning speaking. The result on how they think about teaching media in speaking class is presented in the table below.

\begin{tabular}{|l|c|l|c|l|l|l|}
\hline Statements & Always & $\%$ & Sometimes & \% & Never & $\%$ \\
\hline $\begin{array}{l}\text { Does ESP Lecturer use teaching } \\
\text { media in speaking class? }\end{array}$ & 39 & 38.6 & 52 & 51.5 & 8 & 7.92 \\
\hline $\begin{array}{l}\text { In your opinion, is the use of } \\
\text { teaching media important in a class? }\end{array}$ & 90 & 89.1 & 11 & 10.9 & 0 & 0 \\
\hline
\end{tabular}




\begin{tabular}{|l|l|l|l|l|l|l|}
\hline $\begin{array}{l}\text { Does teaching media increase your } \\
\text { interest in speaking? }\end{array}$ & 65 & 64.4 & 32 & 31.7 & 3 & 2.97 \\
\hline $\begin{array}{l}\text { Does teaching media help you in } \\
\text { understanding the material? }\end{array}$ & 64 & 63.4 & 36 & 35.6 & 1 & 0.99 \\
\hline $\begin{array}{l}\text { Does the lecturer use computer- } \\
\text { based media in the class? }\end{array}$ & 1 & 0.99 & 35 & 34.7 & 64 & 63.4 \\
\hline $\begin{array}{l}\text { In your opinion, is speaking skill } \\
\text { important for your career in the } \\
\text { future? }\end{array}$ & 95 & 94.1 & 3 & 2.97 & 1 & 0.99 \\
\hline
\end{tabular}

Table 2: Students' Opinion about Speaking Class

From the table above, 52 out of 101 students said that the lecturer sometimes used teaching media in a class whereas most of them (90 students) thought that teaching media was important in a class. Moreover, more than a half of them said teaching media will increase their interest in the material and do help them in understanding the material. In contrast, $64 \%$ students said the lecturer never used computer-based media in teaching speaking. However, only $35 \%$ students said that their lecturer sometimes used computer-based media in a class.

Furthermore, the researchers have own interest in English teaching speaking since it is productive skill and the target of speaking is to express the idea freely and spontaneously (Harmer, 2007). Moreover, Ur (2012: 117) stated that among four language competence skills (listening, speaking, reading, and writing), speaking is the most important skill to be learnt. Besides, Brown and Yule (1983) stated that it is often considered one of the most difficult aspects of language learning. It is because they need to combine the grammars, vocabularies, the pronunciation, and also the culture they have learnt together as Nunan (1999) stated that the speaker needs communicative competence which includes not only linguistic competence but also a range of other sociolinguistic and conversational skills. In fact, it is true that students at university level hardly speak and express their idea spontaneously although they have learnt the language or skill since elementary school or junior high school.

Based on the explanation above, the researchers want to know a lecturer's and students' perspective toward Ethnic Snake Game-multimedia usage in a class. According to Moyle, Wijngaards, and Owen (2012: 3), many students think that the more complex the technology uses in a class, the more motivation they have in teaching and learning in class which means the students expect more to the lecturer uses more technology in class. In contrast, the lecturers believe that teacher-centered activity which follows the curriculum design is the best way in teaching and learning process (Campbell, 2012). Hopefully by understanding the lecturer's and students' perspective toward the multimedia, it can help them to increase the teaching and learning activities process in the class.

\section{Method}

The research method used in this study is descriptive since the researchers got the data from giving questionnaire and conducting teaching in speaking class of Electrical Engineering students at UMM. It is in line with Ary (2006: 31), qualitative research is used to seek an understanding about a phenomenon by focusing on the picture rather than breaking it down into variables. The goal is a holistic picture and depth of understanding, rather than a numeric analysis of data.

For the sample of the research, the researchers worked with the $1^{\text {st }}$ semester students from Electrical Engineering major in UMM, East Java, class C. The class was selected because it has been choose by the director of Language Center. Both of the lecturers would become the observer and a lecturer of the class would conduct the teaching and learning process used the proposed multimedia. The multimedia is chosen because it consists of describing people topic which the topic is stated in the syllabus as one of the topics that must be taught in the first semester.

\section{Discussion}

The multimedia usage was conducted in the $7^{\text {th }}$ meeting for Electrical Engineering students on Monday, December $26^{\text {th }}, 2016$. During the teaching and learning activities, the multimedia helped to boosted the atmosphere since the students were very active in following the activities. As Shyamlee and Phil (2012) said that applying multimedia in teaching English can bring some advantages such as cultivating students' interest, promoting students' communication capacity, widening students' knowledge, improving teaching effect, improving interaction between lecturer and students, creating a context for language teaching, and providing flexibility to 
course content. Moreover, in this digital era, students value a technology in learning language to conventional one. It is in line with Nomass (2013) that students like using technology, like computer, in learning language. Beside students, this medium also gives significant impact to the lecturer who can deliver the material easily and in interesting way. Alsulami (2016) said that using technology in teaching English as foreign language can improve students' understanding about the material because they are used to it in their daily life.

There were 24 students and one lecturer when this multimedia was used since it was speaking class which the maximum capacity 25 students. After the activity has been done, the researchers gave a students' questionnaire for students and lecturer's questionnaire for the lecturer in the end of the class. It was to know their opinion toward the medium which had used for learning English. The result is shown in the table below.

\begin{tabular}{|l|l|l|l|l|l|}
\hline No & Statements & $\begin{array}{l}\text { Sangat } \\
\text { Setuju } \\
(\boldsymbol{\%})\end{array}$ & $\begin{array}{l}\text { Setuju } \\
\mathbf{( \% )}\end{array}$ & $\begin{array}{l}\text { Kurang } \\
\text { Setuju } \\
\mathbf{( \% )}\end{array}$ & $\begin{array}{l}\text { Tidak } \\
\text { Setuju } \\
(\mathbf{\%})\end{array}$ \\
\hline 1. & $\begin{array}{l}\text { Multimedia flash yang baru saja } \\
\text { diimplementasikan dikelas sangat } \\
\text { menarik. }\end{array}$ & 46 & 54 & 0 & 0 \\
\hline 2. & $\begin{array}{l}\text { Saya menyukai gambar-gambar } \\
\text { dan animasi gambar yang } \\
\text { disajikan dalam multimedia } \\
\text { tersebut. }\end{array}$ & 29 & 63 & 0 & 8 \\
\hline 3. & $\begin{array}{l}\text { Saya jauh lebih mudah } \\
\text { memahami topic Bahasa Inggris } \\
\text { hari ini dengan menggunakan } \\
\text { multimedia tersebut. }\end{array}$ & 13 & 79 & 0 & 8 \\
\hline 4. & $\begin{array}{l}\text { Belajar Bahasa Inggris hari ini } \\
\text { sangat asyik dan menyenangkan. }\end{array}$ & 29 & 63 & 8 & 0 \\
\hline 5. & $\begin{array}{l}\text { Saya menyukai multimedia ini } \\
\text { dari awal sampai akhir } \\
\text { penyajiannya. }\end{array}$ & 17 & 75 & 0 & 8 \\
\hline 6. & $\begin{array}{l}\text { Saya menjadi tertarik dan } \\
\text { termotivasi dalam belajar Bahasa } \\
\text { Inggris. }\end{array}$ & 25 & 67 & 0 & 8 \\
\hline 7. & $\begin{array}{l}\text { Saya ingin multimedia tersebut } \\
\text { tetap ada dipertemuan selanjutnya } \\
\text { dalam pembelajaran Bahasa } \\
\text { Inggris karena asyik dan } \\
\text { menyenangkan. }\end{array}$ & 25 & 67 & 8 & 0 \\
\hline
\end{tabular}

Table 3. Students' Opinion about Multimedia Usage

From the table above, 54\% students agreed that this multimedia-based medium was interesting and $46 \%$ students even strongly agreed that the medium was interesting. Next, more than a half students which were $63 \%$ students as the agreed that they liked the pictures shown in the medium, 29\% also strongly agreed they like the picture even though $8 \%$ strongly disagreed because of the color produced by the LCD projector affected the color of the pictures. Surprisingly, $79 \%$ of students agreed that they could understand the topic by using this medium but $8 \%$ of students strongly disagreed because they came late to the class and missed some explanation or instruction that caused some confusion. Then, $29 \%$ and $63 \%$ of students strongly agreed and agreed that today's lesson was enjoyable and fun. Luckily, $17 \%$ of students strongly agreed that they liked the medium even from the beginning until the end, and so did $75 \%$ of the students agreed about that. After that, $25 \%$ and $67 \%$ of students strongly agreed and agreed that they were more interested and motivated in learning English although 8\% of students strongly disagreed with item five and six. Last, the same percentage as the previous item strongly agreed and agreed that they wanted this medium for the next meeting yet $8 \%$ of students disagreed. 
As well as the students, the lecturer was also given a checklist in order to know her opinion toward this multimedia-based medium and its guide book. In fact, she gave a positive response about them by giving score four (strongly agree) columns on almost items. The details were presented below.

\begin{tabular}{|l|l|l|l|}
\hline No & Statements & Score & Notes \\
\hline 1. & $\begin{array}{l}\text { Multimedia flash yang baru saja diimplementasikan dikelas sangat } \\
\text { menarik. }\end{array}$ & 4 & \\
\hline 2. & $\begin{array}{l}\text { Warm-up dalam produk ini sangat bagus dan menarik minat dan motivasi } \\
\text { mahasiswa. }\end{array}$ & 3 & 4 \\
\hline 3. & $\begin{array}{l}\text { Gambar-gambar dan animasi gambar yang disajikan dalam multimedia } \\
\text { tersebut sangat menarik. }\end{array}$ & 4 & \\
\hline 4. & Instruksi dan pertanyaan-pertanyaan materi dalam produk sudah jelas. & 4 & \\
\hline 5. & $\begin{array}{l}\text { Dengan menggunakan multimedia ini. Aktivitas-aktivitas siswa menjadi } \\
\text { menyenangkan, kelas menjadi hidup, dan tidak monoton. }\end{array}$ & 4 & \\
\hline 6. & $\begin{array}{l}\text { Terdapat pendalaman materi dalam produk ini dalam bentuk games yang } \\
\text { interaktif. }\end{array}$ & $\begin{array}{l}\text { Buku panduan dari produk ini sudah jelas bahkan sangat membantu dalam } \\
\text { pemahaman dan pengoperasian produk ini. }\end{array}$ & 4 \\
\hline 7.
\end{tabular}

Table 4. The Result of Lecturer' checklist after Try-out

Reflecting on the result of the questionnaire which more than $90 \%$ students gave positive responses in all statement related to the multimedia-based medium and got almost 4 score in every item of the lecturer's checklist, the researchers implied that this multimedia usage is attractive and interesting for the classroom activity. Using interesting medium and which was consisting many attractive pictures can be some triggers since the activity in a class before was monotonous and used fewer medium.

\section{Conclusion}

Imagining the lecturer's and students' expectation toward technology, the Ethnic Snake Game usage would be the answer of the problems. This study was conducted due to lack of technology usage in teaching speaking at UMM. The lecturers were never used a multimedia-based medium in teaching speaking which made the class less attractive and monotonous. Yet, many students thought that multimedia is important and help them during the class. This research enables lecturer and students to correlate their perception in order to improve the learning activity process. Thus, it helps the students to enjoy the class and so does the lecturer.

\section{References}

Alsulami, S. 2016. The Effects of Technology on Learning English as a Foreign Language among Female EFL Students at Effatt College: An Exploratory Study. Studies in Literature and Language, (online), 12(4): 116, (www.cscanada.net/index.php/sl//article/download/7926/9332), retrieved on December 26, 2016.

Avedon, E. 2010. Snakes \& Ladders or Chutes and Ladders. (Online), (http://www.gamesmuseum.uwaterloo.ca/VirtualExhibits/Whitehill/snakes/index.html), retrieved on March 15, 2015.

Ary, D. 2006. Introduction to Research in Education Seventh Edition. Canada: Thomson Wadsworth.

Brown, G., \& Yule, G. 1983. Teaching the Spoken Language. Cambridge: Cambridge University Press.

Campbell, A. 2012. Learning with Technologies: Perceptions and Outcomes in China. In K. Moyle \& G. Wijngaards (Ed.), Student Reactions to Learning with Technologies: Perceptions and Outcomes (pp. 142162). Pennsylvania: IGI Global.

Harmer, J. 2007. The Practice of English Language Teaching. Cambridge: Longman.

Moyle, Wijngaards, and Owen. 2012. Students' Views about Learning with Technologies: A Literature Review. In K. Moyle \& G. Wijngaards (Ed.), Student Reactions to Learning with Technologies: Perceptions and Outcomes (pp. 1-21). Pennsylvania: IGI Global. 
Nomass, B. B. 2013. The Impact of Using Technology in Teaching English as a Second Language. English Language and Literature Studies, 3(1): 111-116.

Nunan, D. 1999. Second Language Teaching \& Learning. Boston: Heinle \& Heinle Publishers.

Smaldino, S. E., Lowther, D. L., \& Russel J. D. 2008. Instructional Technology and Media for Learning (Ninth Edition). New Jersey: Pearson Education Inc.

Shyamlee, S. D. and M Phil, M. 2012. "Use of Technology in English Language Teaching and Learning": An Analysis. IPEDR (33): 150-156, IACSIT Press, Singapore.

Ur, P. 2012. A Course in English Language Teaching (A Completely Revised and Updated Edition of a Course in Language Teaching). Cambridge: Cambridge University Press. 